This is a self-archived version of an original article. This version may differ from the original in pagination and typographic details.

Author(s): Scotson, Mia

Title: Korkeakoulutetut kotoutujat suomen kielen käyttäjinä : toimijuus, tunteet ja käsitykset

Year: 2020

Version: Published version

Copyright: (c) 2020 Kotikielen seura

Rights: In Copyright

Rights url: http://rightsstatements.org/page/lnC/1.0/?language=en

Please cite the original version:

Scotson, M. (2020). Korkeakoulutetut kotoutujat suomen kielen käyttäjinä : toimijuus, tunteet ja käsitykset. Virittäjä, 124(4). https://doi.org/10.23982/vir.98571 


\title{
Korkeakoulutetut kotoutujat suomen kielen käyttäjinä
}

\author{
Toimijuus, tunteet ja käsitykset
}

\author{
Mia Scotson
}

\section{Väitöksenalkajaisesitelmä Jyväskylän yliopistossa 12. syyskuuta 2020}

Suomeen muuttaa vuosi vuodelta yhä enemmän ihmisiä, jotka ovat syntyneet ulkomailla. Eniten Suomeen muuttaneita asuu pääkaupunkiseudulla, jossa ulkomailla syntyneiden ulkomaalaistaustaisten osuus oli vuoden 2019 lopussa jo yli 14 \% koko väestöstä (Tilastokeskus 2020). Suomeen muuttaneet henkilöt eroavat toisistaan hyvin paljon esimerkiksi maahantulosyyn, lähtömaan, kielitaidon ja koulutustason osalta. Myös tarve oppia suomea ja oppimisen lähtökohdat vaihtelevat. Osa Suomeen muuttaneista työllistyy suoraan englanninkielisiin työpaikkoihin, osa puolestaan ilmoittautuu työttömäksi työnhakijaksi, jolloin heidät ohjataan aikuisten maahanmuuttajien kotoutumiskoulutukseen.

Tämän väitöstutkimuksen keskiössä ovat pääkaupunkiseudulla asuvat henkilöt, joilla on ennen Suomeen muuttamista hankittu korkeakoulututkinto tai -opintoja ja jotka osaavat englantia. Tutkimuksen alkaessa osallistujat olivat opiskelleet aikuisten maahanmuuttajien kotoutumiskoulutuksessa noin yhdeksän kuukauden ajan. Kotoutumiskoulutus kestää vajaan vuoden, ja se sisältää kieliopintojen lisäksi työelämätietoutta sekä työssäoppimisjakson. Kielellisenä tavoitteena on Eurooppalaisen viitekehyksen taitotaso B1.1 eli toimiva peruskielitaito, joka tarkoittaa sitä, että henkilö pystyy käyttämään suomea tavallisissa arkielämän tilanteissa. B.1.1-tason kielitaito on myös Suomen kansalaisuuden vaatimus.

Uuden kielen oppiminen vaatii kielen käyttämistä vuorovaikutuksessa. Samalla kun ulkomaalaistaustaisten määrä Suomessa on lisääntynyt, myös Suomen kielimaisema on muuttunut. Esimerkiksi pääkaupunkiseudulla palveluita tarjotaan entistä enemmän englanniksi ja suomalaiset puhuvat mielellään englantia. Olen työs- 
kennellyt kotoutumiskoulutuksessa suomen kielen opettajana sekä työelämäopettajana ja olen huomannut kotoutumiskoulutuksen päättyvän suomen kielen käyttämisen kannalta kriittiseen hetkeen: osa opiskelijoista saavuttaa rohkeuden käyttää suomea vuorovaikutustilanteissa, mutta osa välttelee puhumista suomeksi ja pyrkii käyttämään englantia suomalaisten kanssa.

Väitöskirjani tavoitteena oli selvittää korkeakoulutettuna Suomeen muuttaneiden kokemuksia suomen kielen käyttämisestä luokan ulkopuolella arkielämän tilanteissa ja sitä, mitkä tekijät edistävät ja rajoittavat suomenkielistä vuorovaikutusta. Lisäksi tutkin, mitä tapahtuu suomen kielen käyttämiselle kotoutumiskoulutuksen päätyttyä.

Valitsin tutkimukseni kohderyhmäksi korkeakoulutetut, sillä useimmat heistä osaavat englantia, eli heillä on mahdollisuus valita, mitä kieltä he puhuvat vuorovaikutustilanteissa Suomessa. Lisäksi Tilastokeskuksen vuonna 2015 julkaiseman tutkimuksen mukaan Suomeen muuttaneista henkilöistä nimenomaan korkeakoulutetut osaavat suomea heikoimmin (Nieminen \& Larja 2015). Englantia käytetään monissa työtehtävissä ja opiskelupaikoissa, ja englanti valikoituu helposti yhteiseksi kieleksi suomalaisen keskustelukumppanin kanssa. Yhteiskunnan näkökulmasta korkeakoulutettujen tutkiminen on tärkeää, sillä Suomeen muuttaneet korkeakoulutetut tuovat työmarkkinoille erityisosaamista ilman suomalaisen yhteiskunnan merkittävää panostusta koulutukseen.

Soveltavassa kielitieteessä kiinnostus luokan ulkopuolella tapahtuvaan kielenoppimiseen on kasvanut kuluneen kymmenen vuoden aikana. Korkeakoulutettuja maahanmuuttajia on tutkittu kuitenkin vain vähän paitsi Suomessa myös kansainvälisesti. Suomalaiset tutkimukset ovat keskittyneet pääasiassa ammatillisen kielitaidon kehittymiseen (ks. esim. Kela \& Komppa 2011; Kurhila \& Lehtimaja 2019; Strömmer 2017; Virtanen 2017), ja tietoa korkeakoulutettujen suomen kielen käytöstä esimerkiksi asiointitilanteissa ja vuorovaikutussuhteissa on niukasti. Ammattikieli muodostaa kuitenkin vain osan kielitaidosta, eikä rajan vetäminen ammatillisen ja yleisen kielitaidon välille ole ongelmatonta, minkä vuoksi on tärkeä tutkia myös työtehtävien ulkopuolista kielenkäyttöä.

Kuten sanottu, uuden kielen oppiminen edellyttää aktiivista kielen käyttämistä arkielämän tilanteissa. Koska englantia puhutaan Suomessa nykyään entistä enemmän, englannintaitoiselta suomen kielen oppijalta vaaditaan aloitteellisuutta ja sinnikkyyttä eli toimijuutta, jotta hän pystyy käyttämään suomea. Toimijuus onkin tässä väitöskirjassa keskeinen käsite. Toimijuudesta on monia luonnehdintoja, mutta tutkimuksessani olen hyödyntänyt Sarah Mercerin (2012) määritelmää, jonka mukaan toimijuudessa on kaksi ulottuvuutta: Ensinnäkin on kielenkäyttäjän tunne toimijuudesta, joka tarkoittaa sitä, kuinka toiminnalliseksi henkilö tuntee itsensä sekä yleisesti että suhteessa johonkin tiettyyn tilanteeseen. Lisäksi toimijuuden tunne tarkoittaa tunnetta siitä, että ylipäätään pystyy vaikuttamaan omaan oppimiseensa. Toimijuuden tunteen lisäksi toimijuuteen kuuluu toiminnallinen käyttäytyminen eli se, miten henkilö ilmentää toimijuuttaan osallistumisen ja toiminnan kautta. Vaikka kielenkäyttäjällä olisi toimijuuden tunne, se ei kuitenkaan välttämättä tarkoita sitä, että hän hyödyntäisi mahdollisuutta käyttää suomea, vaan joku tekijä saattaa estää toimijuuden toteuttamisen. 
Tutkimuksessani olen tarkastellut erityisesti sitä, millainen rooli tunteilla ja käsityksillä on kielenkäyttäjän toimijuudessa. Suomalaisissa soveltavan kielitieteen tutkimuksissa käsityksiä on tutkittu aiemminkin, mutta tunteiden merkitys kielenoppimisprosessissa on jäänyt erittäin vähälle huomiolle. Tämä on yksi keskeinen soveltavan kielitieteen alan tutkimusaukko, jota pyrin väitöskirjallani paikkaamaan.

Tutkimukseni viitekehys on ekologis-sosiokulttuurinen. Viitekehys pohjautuu van Lierin 200o-luvun alkupuolella muotoilemaan ekologiseen näkemykseen kielenoppimisesta sekä sosiokulttuuriseen teoriaan, jonka juuret ovat venäläisen, noin sata vuotta sitten eläneen Vygotskyn kirjoituksissa. Ekologis-sosiokulttuurisista lähtökohdista tarkasteltuna toimijuus ei ole vain yksilön ominaisuus, vaan sosiokulttuurinen ympäristö voi sekä tukea että rajoittaa toimijuutta ja suomen kielen käyttämistä (van Lier 2004). Tässä väitöskirjassa tarkastelenkin myös sitä, miten ympäristö vaikuttaa kielenkäyttäjän toimijuuteen.

Väitöskirjani aineisto koostui eri menetelmin hankituista laadullisesta aineistosta. Tutkimushaastattelut toteutin kahdessa vaiheessa: Ensimmäinen haastattelukierros oli kotoutumiskoulutuksen loppupuolella, ja tällöin haastattelin 18 osallistujaa. Toinen haastattelukierros oli vuoden kuluttua kotoutumiskoulutuksen päättymisestä, ja siinä oli mukana 11 haastateltavaa. Toisen keskeisen aineiston muodostivat visuaaliset narratiivit eli osallistujien tekemät piirrokset selityksineen. Yhteensä 59 korkeakoulutettua kotoutumiskoulutuksen opiskelijaa piirsi kaksi kuvaa itsestään suomen kielen käyttäjänä. Toinen kuvista sijoittui nykyhetkeen ja toinen tulevaisuuteen. Muu aineisto muodostui kyselystä $(n=77)$, kirjoitustehtävästä $(n=55)$, tallennetuista kokemuksista $(n=11)$ ja sähköpostikyselystä $(n=14)$. Analysoin aineiston pääasiassa teoriaohjaavan sisällönanalyysin avulla. Lisäksi visuaalisten narratiivien analyysissä käytin Kressin ja van Leeuwenin (2006) mallia kuvien tulkinnasta ja toisessa osatutkimuksessa hyödynsin positioanalyysia (van Langenhove \& Harré 1999).

Väitöskirja sisältää kolme osatutkimusta eli kolme julkaistua artikkelia ja yhteenvetoosion. Ensimmäisessä osatutkimuksessa (Scotson 2018b) keskityin 102 visuaaliseen narratiiviin eli opiskelijoiden piirroksiin ja niistä kirjoitettuihin selityksiin ja tutkin niissä esiintyvää toimijuutta. Selvitin, millaista toimintaa ja tunnetta sekä esineitä, ihmisiä ja paikkoja visuaalisissa narratiiveissa on kuvattu. Toisessa osatutkimuksessa (Scotson 2018a) tarkastelin 17 haastatellun henkilön kokemuksia kielivalinnoista vuorovaikutuksessa ja sitä, mitkä tekijät kielivalintoihin vaikuttivat. Kolmas osatutkimus (Scotson 2019) käsitteli suomen kielen käyttämiseen kytkeytyviä tunteita sekä sitä, miten tunteet ja käsitykset ovat yhteydessä osallistujien toimijuuteen. Tutkin myös, miten tunteet, käsitykset ja toimijuus muuttuivat kotoutumiskoulutusta seuraavan vuoden aikana.

Väitöskirjani tulokset osoittavat, että kielenkäyttäjän tunteilla ja käsityksillä on keskeinen merkitys toimijuudelle ja suomen kielen käyttämiselle. Eniten tunteita aiheuttivat suulliset kielenkäyttötilanteet luokan ulkopuolella. Aineistossa ilmeni negatiivisia tunteita kuten pelkoa, huolta ja hermostuneisuutta, joita voidaan pitää niin kutsuttuna kieliahdistuksena. Negatiiviset tunteet koskivat sekä oman puheen tuottamista että puhekumppanin puheen ymmärtämistä. Kielteiset tunteet rajoittivat toimijuutta ja suomen kielen käyttämistä. Osallistujat kyllä havaitsivat tilaisuuksia käyttää suomea, mutta he välttelivät puhumista suomeksi ja turvautuivat englantiin vuorovaikutustilanteissa. 
Keskeinen toimijuutta ja suullista vuorovaikutusta rajoittava tekijä oli virheiden tekemisen pelko, ja siinä tunteet ja käsitykset kietoutuivat toisiinsa. Virheitä pelkäävän osallistujan oppimis- ja kielikäsitys oli formaalinen, eli hän ei nähnyt virheitä luonnollisena osana oppimista, vaan henkilökohtaisena epäonnistumisena. Kielteiset tunteet kytkeytyivät osallistujien käsityksiin itsestä ja omasta kielitaidosta. Esimerkiksi kolmannessa osatutkimuksessa tarkastelin tuloksia kahden avainosallistujan osalta, ja heillä molemmilla oli käsitys itsestään perfektionistina. Perfektionismiin liitetyt piirteet, kuten omaan suoritukseen kohdistuvat korkeat tavoitteet, omien virheiden murehtiminen ja huoli muiden mielipiteistä, aiheuttivat kielteisiä tunteita ja rajoittivat osallistujien suomenkielistä vuorovaikutusta. Osallistujat eivät uskaltaneet puhua suomea, koska pelkäsivät negatiivista arvostelua ja sitä, että virheet vaikuttavat muiden mielikuvaan itsestä. Virheiden pelon taustalla ilmeni myös käsitys oman kielitaidon riittämättömyydestä. Oman kehittyvän kielitaidon vertaaminen natiivipuhujan suoritukseen aiheutti epärealistisia tavoitteita ja heikensi itsetuntoa. Negatiivisia tunteita vuorovaikutustilanteissa synnytti myös se, että osallistujat eivät kyenneet ilmaisemaan todellista minäänsä kehittyvällä suomen kielellään ja tunsivat itsensä tyhmäksi. Esimerkiksi piirrosaineistossa ilmaisuvaikeudet ilmenivät siten, että yksi osallistuja oli piirtänyt itsensä lapseksi ja kaksi muuta koiraksi.

Väitöstutkimukseni tekee näkyväksi sen, että toimijuus ei ole vain yksilön henkilökohtainen ominaisuus, vaan puhekumppanin toiminnalla ja tilannetekijöillä, kuten kiireellä tai tilanteen vaativuudella, on merkittävä vaikutus kielenoppijan mahdollisuuksiin tai haluun käyttää suomen kieltä. Esimerkiksi viranomaiskontakteissa osallistujat käyttivät pääsääntöisesti englantia ja monet halusivat työharjoittelussa tuoda esiin ammatillista osaamistaan englanniksi. Myös kielenkäyttäjän kokemat tunteet ovat monin tavoin riippuvaisia sosiaalisesta ympäristöstä, esimerkiksi puhekumppanin suhtautumisesta ja käyttäytymisestä. Meidän suomen kieltä puhuvien kannalta merkille pantavaa on, että puhekumppanin toiminta voi olla kielenkäyttäjän toimijuutta tukevaa tai rajoittavaa. Hyvin tyypillisiä olivat kokemukset, joissa kielenoppija kertoi aloittaneensa keskustelun suomeksi, mutta puhekumppani vastasi englanniksi. Vaikka tarkoitus olisi ollut ystävällisesti helpottaa vuorovaikutusta, englanniksi vastaaminen saattoi synnyttää kieltä opettelevassa kielteisiä tunteita ja vaikuttaa negatiivisesti käsitykseen omasta kielitaidosta. Kokemuksista ilmeni, että jos puhekumppani vaihtoi kielen englanniksi, keskustelu yleensä jatkui silloin englanniksi. Kielenoppijalta vaadittiin paljon päättäväisyyttä jatkaa keskustelua suomeksi kielen vaihtumisesta huolimatta.

Kielenkäyttäjän tunteet ja käsitykset ovat yhteydessä aiempiin kokemuksiin. Epäonnistuneet kokemukset suomen kielen käyttämisestä voivat johtaa siihen, ettei tulevissa kohtaamisissa edes yritä puhua suomeksi. Toisaalta onnistuneet kielenkäyttökokemukset ja niihin liittyvät positiiviset tunteet, kuten ilo ja ylpeys, vaikuttivat myönteisesti itsetuntoon ja kannustivat käyttämään suomea. Tärkein ympäristöstä johtuva toimijuutta edistävä seikka oli puhekumppanin tarjoama oikea-aikainen tuki, joka mahdollisti suomen kielen oppimisen vuorovaikutuksessa. Kielenoppimista edistävät puhekumppanin ystävällisyys, kärsivällisyys, puheen hidastaminen ja sanotun toistaminen sekä kannustava palaute. Tuloksista käy ilmi, että huomaavaisen, oikea-aikaista tukea tarjoavan puhekumppanin avulla myös lähtökohtaisesti ahdistunut kielen- 
käyttäjä voi selviytyä tilanteesta suomeksi. Myönteiset kokemukset vaikuttivat käsityksiin omasta kielitaidosta, antoivat itseluottamusta ja vahvistivat osallistujien toimijuuden tunnetta. Koska sosiaalisella ympäristöllä on keskeinen merkitys kielenoppimisessa, suomalaiset eivät ole sivustakatsojia kielikysymyksissä, vaan jokainen meistä suomea puhuvista voi edesauttaa maahan muuttaneen kielenoppimista.

Kolmannessa osatutkimuksessa tarkastelin kahden avainosallistujan kautta, miten suomen kielen käyttäminen jatkui kotoutumiskoulutuksen loputtua. Keskeinen tutkimustulos oli, että vuoden kuluessa osallistujien toimijuus suomen kielen käyttäjänä kehittyi eri suuntiin. Kotoutumiskoulutuksen lopussa molemmat osallistujat kokivat negatiivisia tunteita suomenkielistä vuorovaikutusta kohtaan. Vuoden kuluttua toteutetussa haastattelussa ilmeni, että toisen avainosallistujan puhumisen pelko oli niin voimakas, että hän ei kotoutumiskoulutusta seuranneen vuoden aikana käyttänyt lainkaan suomea vuorovaikutustilanteissa, vaan keskittyi oman ammatillisen uransa edistämiseen englanniksi. Sen sijaan toisen avainosallistujan suomen kielellä puhumiseen liittyvät tunteet ja käsitykset muuttuivat, sillä hän joutui jatkuvasti tilanteisiin, joissa hänen oli pakko puhua suomea. Onnistuneet kielenkäyttökokemukset, oma kokemus edistymisestä ja positiivinen palaute vahvistivat hänen toimijuuttaan, itsetuntoaan ja käsitystä omasta osaamisesta. Vuoden kuluttua osallistuja ei enää juurikaan kokenut negatiivisia tunteita käyttäessään suomen kieltä eikä pelännyt virheitään. Toisessa haastattelussa hän totesi: "Nyt minä ymmärrän, joskus parempi puhua virhien kanssa kuin ei puhua suomea ollenkaan." Omien käsitysten, kokemusten ja tunteiden reflektointi auttoi osallistujaa ymmärtämään virheiden tekemisen pelon olevan yhteydessä hänen omiin käsityksiinsä itsestä täydellisenä opiskelijana. Kielenkäyttötilanteessa koettujen tunteiden ja käsitysten tietoinen jäsentely voi siis edistää kielenoppimisprosessia. Sen vuoksi tunteiden ja käsitysten merkitys kielenoppimisessa olisi syytä huomioida myös kielenopetuksessa sekä kieltenopettajien koulutuksessa.

Vaikka väitöskirjassani painottuivat negatiiviset, toimijuutta rajoittavat tunteet, tärkeä positiivinen tunne oli toivo, joka ilmeni ennen kaikkea visuaalisissa narratiiveissa, kun osallistujat kuvasivat itseään kielenkäyttäjänä tulevaisuudessa. Tulevaisuuteen tähtäävistä piirroksista ilmeni, että osallistujien käsitys omasta toimijuudestaan suomen kielen käyttäjänä tulevaisuudessa oli hyvin myönteinen: monet osallistujat kuvasivat itsensä puhumassa sujuvasti suomea työpaikoillaan. Lopuksi haluankin todeta, että jotta tämä piirroksissa kuvattu visio toteutuisi, se vaatii meitä kaikkia suomea puhuvia pohtimaan omaa käyttäytymistämme ja kielenkäyttöämme vuorovaikutustilanteessa, jossa kohtaamme suomea opettelevan henkilön.

\section{Lähteet}

Kela, Maria - KompPa, Johanna 2011: Sairaanhoitajan työkieli - yleiskieltä vai ammattikieltä? Funktionaalinen näkökulma ammattikielen oppimiseen toisella kielellä. Puhe ja kieli 31 s. 173-192.

Kress, Gunther - Leeuwen, Theo van 2006: Reading images. The grammar of visual design. London: Routledge. 
Kurhila, Salla - Lehtimaja, Inkeri 2019: Ammattikielen tilanteisuus kielenoppimisen haasteena. Esimerkkinä hoitoala. - Lari Kotilainen, Salla Kurhila \& Jyrki Kalliokoski (toim.), Kielenoppiminen luokan ulkopuolella s. 143-171. Helsinki: Suomalaisen Kirjallisuuden Seura.

Langenhove, Luk van - Harré, Rom 1999: Introducing positioning theory. - Rom Harré \& Luk van Langenhove (toim.), Positioning theory. Moral contexts of intentional action s. 14-31. Blackwell: Cambridge.

LIER, LEO VAN 2004: The ecology and semiotics of language learning: A sociocultural perspective. Boston: Kluwer Academic.

Mercer, SARAh 2012: The complexity of learner agency. Apples - Journal of Applied Language Studies 6 (2) s. 41-59. http://urn.fi/URN:NBN:fi:jyu-201302041153.

Nieminen, TARJA - LARJA, LiISA 2015: Suomen tai ruotsin kielitaito vähintään keskitasoa kolmella neljästä ulkomaalaistaustaisesta. - Tarja Nieminen, Hanna Sutela \& Ulla Hannula (toim.), Ulkomaista syntyperää olevien työ ja hyvinvointi Suomessa 2014. Helsinki: Tilastokeskus s. 43-54. http://www.stat.fi/tup/maahanmuutto/art_2015-11-02_003.html.

Scotson, Mia 2018a: Korkeakoulutettujen maahanmuuttajien kielivalinnat vuorovaikutuksessa. Prologi. Puheviestinnän vuosikirja 2018 s. 44-59. https://doi.org/10.33352/ prlg.95929.

— 2018b: Toimijuus korkeakoulutettujen suomen oppijoiden visuaalisissa narratiiveissa. Lotta Lehti, Pauliina Peltorinne, Sara Routarinne, Veijo Vaakanainen \& Ville Virsu (toim.), Uusia lukutaitoja rakentamassa. Building new literacies s. 206-230. Suomen soveltavan kielitieteen yhdistyksen julkaisuja 76. Jyväskylä: Suomen soveltavan kielitieteen yhdistys AFinLA. https://doi.org/10.30661/afinlavk.69056.

2019: Suomen kielen käyttämiseen liittyvät tunteet, käsitykset ja toimijuus. Apples Journal of Applied Language Studies 13 (3) s. 107-129. https://doi.org/10.17011/apples/ urn.201910224568.

Strömmer, Maiju 2017: Mahdollisuuksien rajoissa. Neksusanalyysi suomen kielen oppimisesta siivoustyössä. Jyväskylä Studies in Humanities 336. Jyväskylä: Jyväskylän yliopisto. http:// urn.fi/URN:ISBN:978-951-39-7265-3.

Tilastokeskus $2020=$ Tilastokeskuksen Px-Web-tietokannat. Syntyperä taustamaanosittain sukupuolen mukaan alueittain, 1990-2019. Helsinki: Tilastokeskus. http://pxnet2.stat.fi/ PXWeb/pxweb/fi/StatFin/StatFin_vrm_vaerak/? tablelist=true (4.8.2020).

Virtanen, Aija 2017: Toimijuutta toisella kielellä. Kansainvälisten sairaanhoitajaopiskelijoiden ammatillinen suomen kielen taito ja sen kehittyminen työharjoittelussa. Jyväskylä Studies in Humanities 311. Jyväskylä: Jyväskylän yliopisto. http://urn.fi/URN:ISBN:978- 951-39-7021-5.

Mia Scotson: Korkeakoulutetut kotoutujat suomen kielen käyttäjinä. Toimijuus, tunteet ja käsitykset. JYU Dissertations 271. Jyväskylä: Jyväskylän yliopisto 2020. Väitöskirja on luettavissa osoitteessa http://urn.fi/URN:ISBN:978-951-39-8259-1.

Kirjoittajan yhteystiedot:

etunimi.sukunimi@gmail.com 